\title{
Fostering low-carbon production and logistics systems: framework and empirical
}

\section{evidence}

\begin{abstract}
This work proposes and empirically tests a new framework for evaluating the relationship between stakeholder pressures, the adoption of low-carbon operations practices and firms' carbon performance. It seeks to expand upon stakeholder theory and the natural-resource-based view (NRBV) to understand further the role of operations management in a low-cabrrbon environment. We conducted a survey of manufacturing companies located in Brazil. Our theoretical hypotheses were tested through the Partial Least Squares method with bias-corrected and accelerated (BCA) bootstrap confidence intervals. The key findings encapsulate a mixture of expected and unexpected research results: (i) stakeholder pressures influence both barriers and motivators for decarbonising operations management practices; (ii) a variety of barriers and motivators significantly affect the adoption of low-carbon operations management practices; (iii) developing positive relationships with stakeholders is important to overcome barriers from the external environment and enhance organisational competitiveness; (iv) low-carbon operations management has an overall effect on firms' carbon performance; However, unexpectedly: ( $v$ ) firms seem to face difficulties in understanding stakeholder pressures when developing low-carbon products and logistics, due to a lack of awareness of the sources of barriers to the adoption of low-carbon management practices; (vi) in terms of stakeholders, competitors tend to exert significant pressure towards the adoption of low-carbon operations, while government does not; (vii) more research is necessary to better understand the apparent weak link between low-carbon logistics and firms' low-carbon performance. Thus, our findings offer new information for the sustainable production research community, as well as insights and directions to production research practitioners in supporting their planning and operations management.
\end{abstract}

Keywords: Sustainable Operations; Low-carbon Economy; Low-carbon Operations Management; Logistics; Green Supply Chain Management; Sustainable Manufacturing.

\section{Introduction}

Achieving more sustainable production has garnered the attention of the production research community and its leading scholars (Dolgui, 2018). The latest Paris Agreement, ratified in 2015, explicitly includes and reinforces the need for nations with emerging economies to adopt carbon reduction policies, an action which has the potential to influence the adoption of carbon reduction efforts by organisations throughout the world. Consequently, emerging economies have recently been facing pressure to transition towards a greener economy and to adopt globally recommended best practices in green operations (Mani et 
al., 2018; Seles et al., 2016; Teixeira et al., 2012). Research into the barriers and motivations that companies encounter when pursuing low-carbon operations management can play a vital role in supporting effective decision-making in regard to climate change (Henriques and Catarino, 2016; Herrmann and Guenther, 2017; Jeswani et al., 2008). To augment such research, scholars need to further investigate the role of operations in this field and develop a broader understanding in the context of both developed and emerging economies (Jabbour et al., 2019). This study introduces a framework with strong theoretical underpinnings to address that need.

Drawing on stakeholder theory (de Gooyert et al., 2017) and the natural-resource-based view (NRBV) of the firm (Hart and Dowell, 2011), this study sheds light on the role of stakeholders in firms' carbon performance and the adoption of low-carbon operations management practices, which include improvements in product design, management models, transformation processes and equipment with the goal of minimising carbon emissions and energy consumption (Du et al., 2015), within the context of the Brazilian economy. The research offers insights into operations and carbon reduction, and fills gaps identified in the existing literature.

The existing literature reports divergence in stakeholders' roles and organisations' consequent responses to climate change in a decarbonised economy (Penz and Polsa, 2018). While the literature suggests many benefits of climate change strategies (Hoffman, 2005;), it also documents the difficulties of implementing decarbonising initiatives (Herrmann and Guenther, 2017; Eisenack et al., 2014). For example, recent industry reports suggest that there is no harmonised and homogenous pattern of organisational responses to climate change across Latin America (CDP, 2015), Asia, North America, and Europe (CDP, 2014). Therefore, it appears that organisational actions to combat the consequences of climate change have not been standardised, likely due to difficulties in the implementation of low-carbon initiatives (Paul et al., 2017). The existence of a variety of barriers to and motivations for pursuing a decarbonised production system (Tsalis and Nikolaou, 2017) may explain the different organisational responses to the consequences of climate change; further research is therefore necessary to understand organisational barriers and motivations towards decarbonised production systems.

Recent studies have reported that pressure from stakeholders drives some organisational responses to climate change (Liu, 2018; Cadez et al, 2018; Littlewood et al., 2018; Damert et al., 2017; Abreu et al., 2017). The question is whether such pressure from stakeholders' triggers motivations and barriers towards the adoption of low-carbon operations practices. Therefore, this article concerns the following research questions: (a) have stakeholders influenced barriers and motivations for the adoption of low-carbon operations practices? (b) have barriers and motivations created by stakeholders influenced the adoption of low-carbon operations practices? and (c) has the adoption of low-carbon operations practices affected organisational low-carbon performance? 
To date, research into low-carbon operations, which involve designing products with a low-carbon footprint and carbon-efficient manufacturing and logistics processes, has focused on specific practices, such as low-carbon supply chains (Damert et al., 2018; Luo et al., 2017). There are few comprehensive studies that simultaneously include products, processes, and logistics (Böttcher and Müller, 2015). The majority of empirical studies are geographically limited, with a particular emphasis on China (e.g. Luo et al., 2017), India (e.g. Dubey et al., 2016) and Germany (e.g. Böttcher and Müller, 2015).

Stakeholder theory and the NRBV have the potential to provide insights to further the understanding of low-carbon operations management. Research in this field can benefit from this joint theoretical underpinning because organisational motivation for the adoption of sophisticated sustainable management practices - such as low-carbon operations management - may be triggered by stakeholder pressure and the search for competitive advantage, and the principles of NRBV can explain the differences in companies' responses to environmental issues (Penz and Polsa, 2018).

This work proposes an original theoretical framework integrating constructs that have previously been studied only separately, namely stakeholder pressure, barriers, motivators, low-carbon operations practices and firms' carbon performance. Empirical evidence from Brazilian companies sheds additional light on these relationships. The aforementioned fragmentation in the existing research is due to articles tending to limit themselves to identifying motivations and/or barriers to the adoption of low-carbon operations initiatives (Chu and Schroeder, 2010; Ng et al., 2013, Liu, 2012; 2014; Zhenggang et al, 2017), or to analyse solely the effects of stakeholders and/or motivators on initiatives to reduce $\mathrm{CO}_{2}$ emissions (Boiral et al., 2012; Palsson and Kovács, 2014; Böttcher and Müller, 2015; Lee and Kim, 2015; Yafei et al., 2018). These studies also focus predominantly on high-income countries, while evidence from emerging economies remains a relatively open question.

The key contribution of this article is the unification of theoretical angles and constructs that have been fragmented in previous literature, combined with insights from Brazil, a top-10 economy which is an industrial powerhouse in Latin America and promises to maintain a presence among the top global economies for decades to come (Jabbour et al., 2013). In this vein, our article aims to advance and enrich recent literature on low-carbon operations (Jabbour et al., 2019; Deng, Lv, Huang, Wan, \& Li, 2020; Qin, Han, Wei, \& Xia, 2020), by identifying essential implications that scholars should consider, especially when considering emerging economies. Furthermore, this article highlights robust, practical insights and implications for production research practitioners. In this regard, we provide helpful directions concerning the dynamics as managers adopt strategies to improve low-carbon operations production and their accompanying logistics systems.

This study is organised as follows. After this introductory section, the theoretical framework and hypotheses are presented in Section 2. Following this are the research methodology in Section 3, analysis of 
results in Section 4, and discussion in Section 5. Finally, conclusions are presented in Section 6, and the implications for multiple beneficiaries of the research are highlighted along with the limitations of this study, which may inform future research.

\section{Theoretical framework and development of hypotheses}

2.1. Stakeholder Theory, Natural Resource Based View Theory and low-carbon operations management practices

Stakeholders constitute any group or individual that may affect or be affected by an organisation's goals (Freeman, 1984). Stakeholder theory links external environmental changes to organisations' need to dynamically adjust their routines and strategies in response to their stakeholders, in order to avoid underperformance (Freeman, 1984). Stakeholders can paradoxically present a source of both risk and cooperation for organisations and, consequently, can be either a motivation or a barrier for organisational decisions and operations. Thus, stakeholders must be considered when making strategic decisions (Savage et al., 1991). The level of pressure exerted by these groups can vary (de Gooyert et al., 2017), and organisations can advance from a reactive to a proactive environmental management approach by managing and building relationships with stakeholders (Baranova and Meadows, 2017).

Stakeholder theory has been utilised to connect the themes of sustainable business management and climate change. According to Daddi et al. (2018), stakeholder theory has supported the understanding that stakeholder pressure influences carbon disclosure, and that organisational responses to climate change rely on the importance of stakeholders.

Low-carbon operations management includes the integration of carbon efficiency into the planning, execution, and control of business processes to gain competitive advantage. Low-carbon operations embrace the development of low-carbon products, production and logistics processes (Böttcher and Müller, 2015).

Low-carbon products aim to reduce the amount of carbon emissions throughout the development and consumption stages of products, including more energy-efficient product design, which reduces these emissions throughout a product's life cycle (Lee, 2012; Wesseling et al., 2017). Low-carbon processes include the development of energy-efficient processes to reduce greenhouse gas emissions and the measurement and maintenance of a carbon inventory for processes (Tang and Zhou, 2012; Furlan Alves Matos, et al., 2017). Low-carbon logistics relate primarily to modes of transport, one of the largest sources of atmospheric emissions due to the consumption of fossil fuels (Tang and Zhou, 2012; Haddad-Sisakht and Ryan 2018, 2018). Logistics managers can reassess modes of transport and maximise the use of shipping space in order to minimise their carbon footprint (Dey et al., 2011; Han et al., 2017).

Palsson and Kovács (2014), for instance, find that stakeholder theory helps in understanding organisations' motivations for reducing carbon emissions in transport activities. A summary of motivations and barriers to low-carbon operations management can be found in Table 1. In each study cited, stakeholders 
(e.g. employees, shareholders, government, customers, and competitors) were found to play a significant role, due to the fact that stakeholders are environmental change "forcers" (Valero-Gil et al., 2017). For example, Garcés-Ayerbe et al. (2012) suggest that proactive environmental strategies, which include lowcarbon operations, are the result of organisational efforts to meet stakeholders' environmental demands. This means that stakeholders are a source of motivation for low-carbon operations. However, climate change actions may be limited in contexts in which some regulatory bodies are less stringent (Amran et al., 2016; Chu and Schroeder, 2010), which means that experiencing less pressure from stakeholders may act as a barrier to low-carbon operations management initiatives. Barriers to low-carbon operations must be identified in order to be overcome, and all parties and their actions, including single stakeholders, are responsible for creating and reducing barriers to climate change initiatives (Eisenack et al., 2014).

The studies shown in Table 1 further support stakeholder theory. Not only does stakeholder pressure increase organisations' motivation to adopt certain environmental practices, but it may also reduce barriers (Delgado-Ceballos et al., 2012). For example, managers can utilise stakeholder pressure to argue for resources needed to implement environmental policies or to build knowledge in an organisation. The more that managers consider high environmental stakeholder pressure to improve processes, enhance resources, and even increase competitive advantage (Valero-Gil et al., 2017), the greater barriers can be overcome.

PLEASE INSERT TABLE 1 HERE

Considering the above, it can be hypothesised that:

H1a - Stakeholder pressure negatively influences barriers to the adoption of low-carbon operations

$H 1 b$ - Stakeholder pressure positively influences motivations for the adoption of low-carbon operations

More recent studies, for instance, have reported that pressure from stakeholders drives some organisational responses to climate change (Liu, 2018; Cadez et al., 2018; Littlewood et al., 2018; Damert et al., 2017; Abreu et al., 2017); however, these studies have only tested the influence of stakeholder pressure on organisational carbon management or carbon strategies. There is a lack of analysis of the influence of stakeholder pressure on the adoption of the three low-carbon operations management practices mentioned above, namely low-carbon products, low-carbon processes, and low-carbon logistics, which represent different organisational responses due to stakeholder pressure. Thus, this article tests the following hypotheses.

H1c - Stakeholder pressure influences the adoption of low-carbon products 


\section{H1d-Stakeholder pressure influences the adoption of low-carbon processes \\ H1e-Stakeholder pressure influences the adoption of low-carbon logistics}

The NRBV argues that firms' internal resources and sustainable management capabilities should be developed to improve organisational competitiveness (Hart and Dowell, 2011). By investing in environmental improvements, organisations can enhance their sustainable performance, which is similar to the fundamental principles of the resource-based view of the firm (Barney, 1991). Environmental resources and capabilities may be key factors in overcoming external environmental barriers and improving organisational competitiveness (Martín-de Castro et al., 2016). The NRBV argues that there are three key strategic capabilities: pollution prevention, product stewardship, and sustainable development (Hart and Dowell, 2011). Developing resources and capabilities for carbon emissions reduction is an important competitive response in the transition to a low-carbon economy (Gallego-Alvarez et al., 2015).

The adoption of low-carbon operations management practices can be seen as a strategic capability to respond to stakeholder pressure regarding climate change. Low-carbon processes and low-carbon logistics relate to a firm's pollution prevention strategy, because they aim to increase the efficiency of processes, including carbon efficiency. Low-carbon products relate to the product stewardship strategy, since they change product design features based on a life-cycle perspective. Thus, it can be argued that based on the NRBV, the adoption of low-carbon operations practices provides an organisational response to stakeholder pressure related to the consequences of climate change. In addition, the adoption of low-carbon operations practices may vary, because the level of pressure exerted by stakeholders can also vary (de Gooyert et al., 2017).

Some studies have discussed the role of stakeholders in influencing organisational responses to climate change. According to Sprengel and Busch (2011), organisational responses and strategies to reduce $\mathrm{CO}_{2}$ emissions do not tend to differ according to the source of stakeholder pressure. Betts et al. (2015) seem to partially agree with Sprengel and Busch (2011), suggesting that stakeholder pressure is experienced differently by different companies due to individual features of the sector to which they belong. However, according to the NRBV, companies' responses in terms of environmental management practices do not vary depending on stakeholder pressure. It seems that there is conflicting understanding in terms of the effect of stakeholder pressure on organisational responses to reduce $\mathrm{CO}_{2}$ emissions; González-Benito and GonzálezBenito (2006) and Hyatt and Berente (2017) both state that organisational responses to stakeholder pressure differ according to the profile of the relevant stakeholder. Therefore, while stakeholder pressure consistently leads to the adoption of environmental practices by organisations, different stakeholders may apparently drive different environmental responses in organisations. This article contributes to further understanding this last statement. 
Based on the assumptions emerging from the previous hypotheses - i.e., that stakeholder pressure creates barriers and motivations for the adoption of low-carbon operations practices, namely low-carbon products, low-carbon processes, and low-carbon logistics - and on the fact that environmental resources and capabilities may be key factors in overcoming external environmental barriers and improving organisational competitiveness (Martín-de Castro et al., 2016) the following set of hypotheses are proposed:

H2a - The perception of barriers to low-carbon operations negatively affect the adoption of low-carbon products

$\mathrm{H} 2 \mathrm{~b}$ - The perception of barriers to low-carbon operations negatively affect the adoption of low-carbon processes

$\mathrm{H} 2 \mathrm{c}$ - The perception of barriers to low-carbon operations negatively affect the adoption of low-carbon logistics

H3a-The perception of motivations for low-carbon operations positively affect the adoption of low-carbon products

$\mathrm{H} 3 \mathrm{~b}$ - The perception of motivations for low-carbon operations positively affect the adoption of low-carbon processes

$\mathrm{H} 3 \mathrm{C}$ - The perception of motivations for low-carbon operations positively affect the adoption of low-carbon logistics

\subsection{Low-carbon operations management practices and carbon performance}

The rationale for the adoption of carbon reduction initiatives and practices is to reduce environmental damage and improve overall company performance, based specifically on carbon performance (Damert et al., 2017). Carbon performance, an element of environmental performance measurement, means the reduction of carbon emissions associated with organisations' main processes, involving the consumption of energy, carbon emitted, and use of carbon-intense materials per unit of product produced (Böttcher and Müller, 2015). Interestingly, the relationship between corporate adoption of environmental practices and actual environmental performance has not been studied as extensively as has the relationship between adoption of environmental practices and financial performance. The reason for this dearth of studies is that organisations have always been primarily interested in financial performance; additionally, environmental performance and carbon emissions data are much more limited than financial performance data (Doda et al., 2016).

In this matter, there is some ambiguity in the relationship between low-carbon operations and carbon performance (Damert et al., 2017). Few studies have addressed the impact of low-carbon operations practices on the reduction of GHG emissions (Doda et al., 2016). An important aspect of assessing this relationship is determining whether it is worthwhile for organisations to make significant investment in such efforts. It has also been posited that organisations may adopt certain practices as a 'greenwashing' effort, to improve their image, but that resultant environmental performance is not always forthcoming, since the focus in such cases 
is on the signal to the marketplace (e.g. see Wang and Sarkis, 2017). Therefore, further studying the relationship between carbon operations practices and carbon performance benefits the literature of the field by advancing understanding of whether stakeholder pressure is effective in terms of stimulating carbon operations practices and in turn improving organisational carbon emissions reduction (Damert et al., 2017).

Existing studies are conflicted in terms of low-carbon operations, carbon performance and organisational size (Zuraidah et al., 2014). For example, small manufacturers may focus more on process improvements rather than product redesign, which may be mandated by customers (Zailani et al., 2012). Another assumption regarding low-carbon operations, carbon performance and company size is that large firms are likely to adopt carbon strategies or carbon management initiatives when under positive pressure from stakeholders (Liu, 2018).

Thus, based on previous statements regarding the relationship between low-carbon operations practices and carbon performance, it can be hypothesised that:

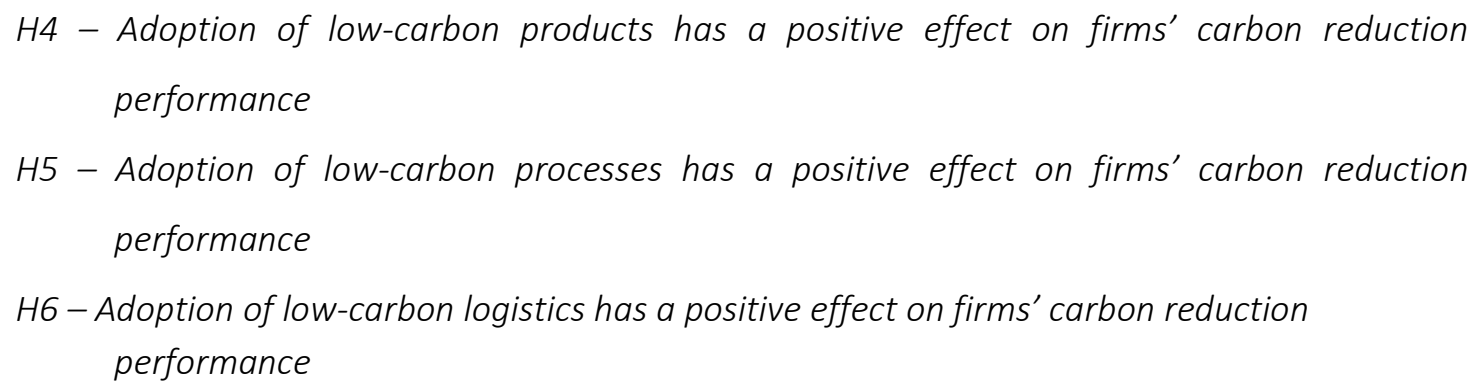

Although the aforementioned hypotheses $\mathrm{H} 4-\mathrm{H} 6$ may be considered non-specific statements, they also have the potential to provide some important insights for the emerging state-of-the-art literature on this topic. Figure 1 depicts a representation of the complex relationships among stakeholders, barriers, and motivations for low-carbon operations management, the adoption of low-carbon operations practices, firms' carbon performance, and firms' size.

\section{PLEASE INSERT FIGURE 1 HERE}

\section{Research design and methodology}

\subsection{Constructs, measures and scale development}

A questionnaire was created based on measures adapted from previously validated studies (Table 2). The most closely related studies on each topic were taken into consideration, according to searching in the Scopus database. Thus, Liu's (2014) and Böttcher and Müller's (2015) articles came to represent the main pillars of the research questionnaire used in this study, in terms of the items and scales of measurement used, as well as questions. The decision to use the same questions and scales as Liu's (2014) and Böttcher and Müller's (2015) research was taken since these authors have already tested these items of measurement in 
studying barriers, motivations, low-carbon operations management, and carbon performance constructs. Variables from Liu's (2014) article are used to describe barriers, while the motivations for low-carbon operations management are based on Böttcher and Müller's (2015) indicators. The stakeholder construct includes customers, government, competitors, employees, suppliers, and media (Clarkson, 1995). Low-carbon operations management (low-carbon products, low-carbon processes, and low-carbon logistics) and carbon performance constructs were also based on Böttcher and Müller's (2015) indicators. A five point Likert-scale was used to measure all items.

The original questionnaire was pre-tested (Synodinos, 2003) with both academics considered experts in the area of sustainable operations management and managers representative of the intended respondents, following the procedure suggested by the literature (e.g. Darroch, 2003). Regarding the group of academics who pre-tested the questionnaire, five were PhD holders and five PhD candidates. Regarding the pre-testing managers, two experts were consulted. The pre-testing phase resulted in a number of improvements to the clarity of certain questions; no questions were dropped at this stage.

Table 2 summarises the constructs, items and scale of measurement.

\section{PLEASE INSERT TABLE 2 HERE}

\subsection{Sampling and data collection procedures}

The sample country selected for this research is Brazil. Brazil is especially pertinent, as a developing economy which has proposed to reduce its greenhouse gas emissions by $37 \%$ by 2020 as part of the COP 21 agreement (Marcondes and Canto, 2015). This represents a bold and risky commitment for a developing country, whose economy might be negatively affected by such an initiative. This agreement therefore shows that Brazil is committed to reducing carbon emissions, and industry will be central to this goal.

Since the complete population size relevant to this study is necessarily unknown, we used the following criteria to identify the target population: (a) companies which manufacture mechanical capital goods, due to the potential environmental degradation caused by their products - these companies may have to adapt their products and processes in order to comply with legal and stakeholder environmental requirements; and (b) companies who are members of the Brazilian Machinery Builders' Association (ABIMAQ) and the National Union of the Component Industry for Auto Parts (Sindipeças). Based on these criteria, we identified 2137 eligible companies as our target population. We then contacted these companies to ask for their agreement to participate in the survey. We received approval from 882 companies for their voluntary participation, constituting our sampling frame. We used a non-probability sampling method, selecting our sample non-randomly based on the responses we received. This method is considered 
appropriate when each element of the sample population does not have the same chance of being chosen as part of the sample. In addition, the use of non-probability sampling is commonly used because it saves time and costs when faced with a large number of population elements (Sekaran and Bougie, 2016).

After the final version of the questionnaire was established, invitations to participate in the research were sent via email to the environmental managers or holders of similar positions in each company of the sampling frame. This respondent profile was selected because environmental managers, in general, are the individuals responsible in their organisation for proposing environmental management policies, implementing environmental management systems and developing environmental reports (Arnaut et al. 2012). Thus, environmental managers are required to collect data on environmental indicators (e.g. carbon emissions) for their organisational processes and to interact with other organisational areas in order to collect such data. Therefore, environmental managers are best qualified to respond to questions related to low-carbon operations management. The email sent to respondents included a web link to access the online version of the questionnaire. We followed up with participants via telephone calls two weeks after the initial email. The survey was conducted over 5 months, from late 2014 to mid-2015, the data was analysed during 2016 and this article was written during 2017. The time frame used in this research is suitable for comparing the findings in terms of the relationships between stakeholder pressure, barriers to and motivations for the adoption of low-carbon operations management practices, and the consequences for organisational carbon performance, both before and after the agreement reached in COP 21, which occurred in 2015. It was therefore possible to check whether the organisations studied have changed their pathway towards a lowcarbon economy due to the COP 21 agreement.

\section{$* * * * * * * * * * * *$ \\ PLEASE INSERT TABLE 3 HERE}

The profile of the companies studied in terms of size is as follows: 8 micro-sized, 20 small-sized, 38 medium-sized and 25 large-sized. All the companies involved have been awarded ISO 9001 and 14001 certifications. Table 2 depicts the sample distribution features in further detail. The sample size obtained proved to be sufficient, taking into account the following parameters. According to Hair et al. (2017), this sample size is sufficient to run a model with statistical power of 0.80 and R-square of 0.25 at the $5 \%$ significance level; with 6 independent constructs in use, the minimum sample size required was 51 . We also reinforced our results using the G*power software, and obtained a minimum sample size of 77 . Additionally, the sample size in this research is similar to that used in other established works in the green production research area. For example, Klassen and Whybark (1999) used a sample of around 70 respondents, Holt and Ghobadian (2009) 60 respondents and Rao (2002) 52 respondents. Additionally, there are other relevant 
studies which use a smaller sample size than that used in this work (Gavronski et al., 2008). Based on the work of Hair et al. (2019), the use of small sample sizes in partial least squares-structural equation modelling (PLSSEM) can be justified when the level of statistical power has been ascertained. Thereby, PLS-SEM can provide unbiased estimation and tend toward the true values. It should be recognized that the greater the sample size used (e.g. 200 cases), the smaller the standard error values produced will be; therefore, the PLS estimation results will be more precise. However, the difference may be very small, as noted by Hui and Wold (1982), meaning that the conclusions drawn will remain unbiased.

We conducted non-response bias testing, comparing respondents who returned the questionnaire early and late. For this we used t-testing, comparing the two groups (early and late responders) by looking at the significance of Levene's test and equality of means. Table 4 shows a significance value of $>0.05$ for the two groups of respondents in the constructs tested, indicating that non-response bias is not a potential threat to our results.

\section{PLEASE INSERT TABLE 4 HERE}

\subsection{Data analysis procedures}

We have chosen to use the Structural Equation Modeling (SEM) approach in this study, which is considered the second generation of multivariate analysis. SEM enables us to examine the relationships between unobserved variables and to test more complex relationships in the realm of quantitative research. In addition, SEM offers a sophisticated approach compared to classical methods such as multiple regression or path analysis. With SEM, analysis can be carried out simultaneously without intervention. Therefore, taking its advantages into account, SEM is a suitable approach for this study. We chose to use variance-based SEM (VBSEM) through partial least squares-structural equation modelling (PLS-SEM) for our data analysis. PLS-SEM provides a flexible approach and is superior when modelling multiple construct interactions about which there is relatively scarce theoretical knowledge (Noonan and Wold 1986; Wold 1986). PLS-SEM is especially useful for the exploration of new theoretical and conceptual frameworks (Henseler 2018), and is particularly effective in the examination of complex relationships between variables; covariance-based SEM (CB-SEM) and traditional regression methods are more limited in this area (Latan 2018; Ramli et al. 2018). However, certain assumptions should be considered when using the PLS model, such as the absence of model misspecification and multicollinearity between predictor variables.

The data analysis method used in this research contains three sub-processes. The first was to assess the measurement model in order to ensure the reliability and validity of each indicator. The second involved 
assessing the structural model through examination of the coefficient of determination $\left(R^{2}\right), Q^{2}$ predictive relevance, effect size $\left(f^{2}\right)$ and goodness of fit model. Finally, in the third stage, we tested our hypotheses using a $95 \%$ confidence interval.

\section{Results}

\subsection{Measurement model assessment}

Our analysis results are reported following the general reporting standards proposed by Latan (2018) for studies using PLS-SEM. First, we analysed the measurement model to ensure that the indicators of each construct were valid and reliable. Here, we tested convergence and discriminant validity as well as construct reliability. Convergent validity was measured using factor loading, for which the values should equal 0.70 , and the average variance extracted (AVE) should equal 0.50. For discriminant validity, we employed the approach called the heterotrait-monotrait (HTMT) ratio. This approach is considered better than the Fornell-Lacker criterion, and HTMT is able to overcome the bias embedded in measurements (Hair et al., 2017). The HTMT value must be less than 0.90 for each construct. As for measuring the reliability of the constructs, we selected $\rho_{c}$ and $\rho_{A}$ as the most appropriate measures. It is recommended that the $\rho_{c}$ and $\rho_{A}$ value must be greater than 0.70. We used the SmartPLS 3 program (Ringle et al., 2015) to analyse the model. As Latan (2018) suggests that authors should disclose the specific settings used in the PLS algorithm, we selected the weighting scheme (path) with the maximum number of iterations at 300. In terms of bootstrapping, we chose a bias-corrected and accelerated ( $\mathrm{BCa}$ ) bootstrap, with a resampling number of 5,000 to obtain structural model results. Table 5 below show the overall measurement model results.

\section{PLEASE INSERT TABLE 5 HERE}

Table 5 above shows the results of convergent validity and construct reliability. The value of the loading factor, the average variance extracted (AVE), and reliability derived from the analysis of the measurement model for all variables are as follows: loading factor $>0.708, \rho_{c} / \rho_{A}>0.70$ and AVE $>0.50$ which meets the recommended requirements (Benitez et al., 2020). However, some measurement model indicators were retained, with the loading factor value being $<0.70$. As stated by Hair et al. (2017, p. 114), the value of the loading factor shows the explained variance in a construct. Therefore, if the AVE value is already greater than 0.5 , an indicator with low loading values can remain in the construct to ensure content validity. The results of the measurement model analysis are shown in Figure 2 below.

\section{PLEASE INSERT FIGURE 2 HERE}




\section{$* * * * * * * * * * * *$ \\ $* * * * * * * * * * * *$ \\ PLEASE INSERT TABLE 6 HERE}

Table 6 shows the results regarding discriminant validity and correlation between constructs. From these results, it can be seen that stakeholder pressure and motivation have the strongest correlation, at 0.641 , followed by low-carbon operations and carbon performance, with 0.625 and 0.498 , and finally barriers and low-carbon operations, with $-0.347,-0.409$ and -0.319 , respectively. The results of the discriminant validity analysis (values above the diagonal line), conducted using the HTMT approach, shows that all HTMT values of the constructs are $<0.90$, indicating that the required rule of thumb is met.

\subsection{Common method bias assessment}

We also assessed the data for common method bias, one of the most important issues discussed in social science research over the past three decades. This bias generally arises from methodological and response variances that affect the correlation between variables measured using the same method (Doty and Glick, 1998; MacKenzie and Podsakoff, 2012). This problem is often associated with self-reporting techniques involving data collection from questionnaire surveys and potential measurement errors. Some researchers suggest methods by which scholars can control this bias (Malhotra et al., 2017) in order to avoid inaccurate results, such as inflated or deflated correlations. Inflation results in a wrongly identified strong relationship between variables and/or support for a theory (type I error), while deflation leads to the relationship between variables being perceived as weak and/or prompting a rejection of the theory (type II error). To redress this issue, we used the full collinearity approach as provided by Kock (2017) in PLS-SEM, by looking at the average variance inflation factor (AFVIF) value. The analysis results show that the AFVIF values obtained $<3.3$, indicating that common method bias poses no threat to our results (see Table 7).

\subsection{Structural model assessment}

After confirming that all the indicators of the variables were reliable and valid (see Figure 2 above), the next step involved assessing the results of the structural model and testing the hypotheses. Since the PLSPM algorithms use the iteration method following multiple regression series, path coefficient interpretation in PLS-PM is equal to the standardisation of regression coefficients. Similarly, interpretation may be applied to adjusted $r$-square, variance inflation factor $(\mathrm{VIF})$, effect size $\left(f^{2}\right)$ and predictive relevance $\left(Q^{2}\right)$ (Hair et al., 2017; Latan, 2018).

Before we illustrate the results of our analysis in this second step, it should be noted that we tested the collinearity of the structural model. To assess collinearity, we used the same measure as in multiple 
regression. VIF values of $<3.3$ are recommended, with values $<5$ still remaining acceptable for all variable predictors in the model (Hair et al., 2017; Latan, 2018). The results of the analysis in Table 7 show that there is no collinearity problem interfering with the results. Furthermore, we evaluated the structural model by looking at the coefficient of determination $\left(R^{2}\right.$ or adjusted $\left.R^{2}\right), f^{2}$ and $Q^{2}$. The coefficient of determination measures the predictive power of the model and represents the amount of variance in the endogenous variable that can be explained by all exogenous variables. A coefficient of determination above 0.20 is considered high in some disciplines, but values between 0.25 and 0.50 are considered valid.

\section{PLEASE INSERT TABLE 7 HERE}

Table 7 indicates that the R-square and Adj. R-square values generated by each endogenous construct are entirely acceptable. These values suggest that the ability of the predictor variables to explain the outcome variables approaches the substantial level (Field, 2016; Wooldridge, 2020). The resulting effect size values of each predictor variable in the model range from 0.01 to 0.69 , thus falling across the small to large categories. The value of the variance inflation factor (VIF) generated for all the independent variables in the model is < 3.3, which indicates that there is no collinearity problem between the predictor variables. The $Q^{2}$ predictive relevance value indicates excellent endogenous variables, i.e. values $>0$, meaning that the model has predictive relevance.

\subsection{Testing hypotheses}

We tested our hypotheses in view of the coefficient parameter and the significant value generated from the 95\% bias-corrected confidence interval of each independent variable. We tested the hypotheses using the one-tailed rather than two-tailed test. Testing hypotheses using a one-tailed test is more appropriate when the hypothesised direction is clear, so as to minimize type II errors (Field, 2016; Wooldridge, 2020). The results of the testing of hypotheses are presented in Table 8 below.

\section{PLEASE INSERT TABLE 8 HERE}

As shown in Table 8, almost all the path coefficients provide significant value (at the $5 \%$ level). Based on this analysis, stakeholders have a significant positive effect on motivations and a significant negative effect on barriers. From the analysis results, we may obtain coefficient values $(\beta)$ for the relationships between Stakeholders $\rightarrow$ Barriers, Stakeholders $\rightarrow$ Motivations and Stakeholders $\rightarrow$ GOProc of $-0.244,0.641$ and -0.074 
respectively, with $95 \%$ bias-corrected and accelerated $(\mathrm{BCa})<0.05$. This means that $\mathrm{H} 1 \mathrm{a}, \mathrm{H} 1 \mathrm{~b}$, and $\mathrm{H} 1 \mathrm{~d}$ are supported. Furthermore, the values of the coefficient $(\beta)$ for the relationships barriers $\rightarrow$ low-carbon operations (products, processes and logistics) are $-0.288,-0.275$ and -0.280 respectively, with $95 \%$ biascorrected and accelerated $(\mathrm{BCa})<0.01$. This means that $\mathrm{H} 2 \mathrm{a}, \mathrm{H} 2 \mathrm{~b}$, and $\mathrm{H} 2 \mathrm{c}$ are supported.

The relationships between motivations $\rightarrow$ low-carbon operations (products, processes and logistics) also yield significant results, with coefficient values $(\beta)$ of $0.405,0.363$ and 0.233 respectively, with $95 \%$ biascorrected and accelerated $(\mathrm{BCa})<0.05$. This means that $\mathrm{H} 3 \mathrm{a}, \mathrm{H} 3 \mathrm{~b}$, and $\mathrm{H} 3 \mathrm{C}$ are supported. Finally, for the relationships between GOProd $\rightarrow$ carbon performance and GOProc $\rightarrow$ carbon performance, the coefficient values $(\beta)$ obtained are 0.207 and 0.521 respectively, with 95\% bias-corrected and accelerated $(\mathrm{BCa})<0.01$. This means that $\mathrm{H} 4$ and $\mathrm{H} 5$ are supported. However, $\mathrm{H} 6$ is not supported.

\subsection{Additional testing}

We also tested for endogeneity bias, which posed another threat to our results. This endogeneity testing was intended to maintain the robustness of our analysis results. Endogeneity bias generally arises from the selection of non-random sample, and may manifest through bidirectional relationships between variables or as a result of the effect of omitted variables (Ketokivi and McIntosh, 2017; Peel, 2018). Endogeneity bias distorts the PLS algorithm and threatens the validity of the results. To clarify this issue, we used the Heckman test to obtain propensity scores in assessing endogeneity with the help of the Stata program. We found that the significance obtained from both models remained the same (see Table 9), which indicates that endogeneity bias is not a potential threat to our results.

\section{PLEASE INSERT TABLE 9 HERE}

\section{Discussion}

Underpinned by stakeholders' theory (de Gooyert et al., 2017) and the natural-resource-based view (NRBV) of the firm (Hart and Dowell, 2011), this study sheds light on the role of stakeholders in firms' carbon performance and the adoption of low-carbon operations management practices (processes, products, and logistics) in the context of an emerging economy (Brazil). Overall, this research offers findings which are both expected and unexpected based on the current literature and relevant theory, and adds insights into the application of stakeholders' theory to low-carbon operations management by highlighting that competitors tend to influence the transition to low-carbon operations more significantly than other important stakeholders, which adds to the debate on the role of stakeholders in operations management (de Gooyert et al., 2017). We also add some new insights to the NRBV theory by suggesting that, while the majority of lowcarbon operations practices tend to relate positively to firms' performance, this may not be always the case 
for low-carbon logistics, which requires more reflection from academics working in this area (Hart and Dowell, 2011).

Precisely, this work encapsulates five main results that contain both expected and unexpected discoveries. The main findings of the research are: (a) stakeholder pressure exerts influence on both barriers and motivations for adopting low-carbon operations management practices; (b) stakeholder pressures, especially from competitors, tend to impact low-carbon processes, while significant evidence has not been found for the same type of impact on low-carbon products and low-carbon logistics; (c) both barriers and motivators tend to influence the adoption of low-carbon operations management practices; (d) the adoption of low-carbon operations management affects the carbon performance of the organisations studied, although low-carbon logistics proved to be an exception; and (e) the larger the size of the firm, the more intense the adoption of low-carbon processes and logistics.

Stakeholders influence the barriers and motivations for the adoption of low-carbon operations management practices. Consequently, organisations should manage their relationships with stakeholders in order to mitigate the barriers to the adoption of low-carbon operations management practices, following Delgado-Ceballos et al. (2012) who suggest that integration with stakeholders can alleviate internal barriers. Additionally, organisations should monitor the demands of customers and government in terms of low-carbon products, processes, and logistics in order to maintain good relationships with these stakeholders, as is explained further in the following paragraphs. A positive stakeholder relationship increases performance and allows stakeholders to act as a source of support for low-carbon strategies (Baranova and Meadows, 2017). This finding reinforces the need to further explore the complex relationship between stakeholder theory and operations management (de Gooyert et al., 2017).

The findings of this work go beyond recognising that stakeholders are relevant to implementing environmental practices (Sarkis et al., 2010), also incorporating the complexity of dealing with low-carbon practices. We found that stakeholders affect the adoption of low-carbon processes; however, stakeholders are most concerned with low-carbon processes and tend not to be involved in practices around low-carbon products and logistics. Generally, it is manufacturing and transformative production processes which create the most significant risks to the environment. Because of this, stakeholders tend to be more sensitive to environmental issues such as emissions and other forms of pollution, which emerge during manufacturing (Jabbour, 2010).

Additionally, the survey results show that, quite unexpectedly, competitors were acknowledged as the most prominent stakeholders in influencing low-carbon operations initiatives. As a result, we can conclude that the organisations studied have been driven by competitors pursuing low-carbon operations management, and specifically low-carbon processes, which are likely to result in an increase in operational efficiency (e.g. due to the use of energy/carbon efficient equipment) and competitiveness. This finding is a 
novel insight of this article. Previous literature has identified customers and government as the most relevant stakeholders in terms of adopting environmental practices (Liu, 2012, 2014; Zailani et al., 2012; Palsson and Kovács, 2014; Lee and Kim, 2015, Weber and Cabras, 2017). Furthermore, according to Hoogendoorn et al. (2015), Lee and Kim (2015) and Zailani et al. (2012), government stakeholders tend to influence the adoption of low-carbon production practices, while suppliers primarily influence the adoption of low-carbon processes (Zuraidah et al., 2014). In summary, competitors prompt organisations to adopt low-carbon processes, which can potentially improve operational efficiency and competitiveness. Thus, improved low-carbon processes are a particular source of competitive distinction. Additionally, different types of stakeholders can influence the adoption of different low-carbon operations practices as a corporate response to climate change. Therefore, this article contributes to the debate addressed by González-Benito and González-Benito (2006), Sprengel and Busch (2011), Betts et al. (2015), and Hyatt and Berente (2017) and reinforces the idea that NRBV theory can explain differences in companies' responses to environmental issues (Penz and Polsa, 2018) by means of the adoption of low-carbon operations practices.

The findings from our survey demonstrate that barriers and motivations impact the adoption of lowcarbon operations practices. The major barrier identified was a lack of social and consumer context for the reduction of $\mathrm{CO}_{2}$ emissions. In terms of reduction in carbon emissions, the most important stakeholder for the organisations surveyed was competitors, which can be considered an unexpected research result, suggesting that the search for enhanced competitiveness can drive firms towards the adoption of low-carbon operations. The main barrier and motivation both align with the results of $\mathrm{Ng}$ et al. (2013), and the main motivation also aligns with the findings of Böttcher and Müller (2015). The results show that customer stakeholders are not the main influencers for low-carbon operations initiatives; however, a lack of social and consumer context for the reduction of $\mathrm{CO}_{2}$ emissions is related to customers' behaviour. Thus, the organisations studied seem to have experienced difficulty in identifying customer stakeholders as a barrier to the adoption of low-carbon operations practices. The consequence of such a lack of awareness of the source of barriers is that critical stakeholders may not be adequately managed. According to Baranova and Meadows (2017), building environmental capabilities through stakeholder engagement is fundamental for continuity and the success of sustainable business strategies, especially in the context of transitioning to a low-carbon economy. Moreover, Gallego-Allvarez et al. (2015) state that developing resources and capabilities is relevant for the reduction of carbon emissions. Consequently, through the NRBV perspective, developing strong relationships with stakeholders is important to overcome barriers from the external environment and enhance organisational competitiveness (Martín-de Castro et al., 2015).

The adoption of low-carbon operations management practices assists organisations in pursuing improved carbon performance, especially in terms of reducing the $\mathrm{CO}_{2}$ emissions of processes and products. Surprisingly, no significant relationship between low-carbon logistics practices and carbon performance was 
identified (H6). We may begin to explore this finding through the following tentative explanations; however, this outcome certainly deserves further investigation. First, the adoption of low-carbon logistics seems to be a considerably complex process, which requires more variables to capture its complexity than the three variables used in this work, which was inspired by Böttcher and Müller (2015). Additionally, previous literature has found that low-carbon logistics initiatives can leverage firms' environmental and financial performance, supported by inter-organizational integration, which is in turn reinforced by collaboration, knowledge transfer and information sharing (Qian, Wang, Liu, \& Zhang, 2019). Legislation and regulation can play an important role in explaining the adoption of low-carbon logistics practices (Laosirihongthong, Adebanjo, \& Choon Tan, 2013); however, this is not the focus of our current research framework. Furthermore, the adoption of lowcarbon logistics can suffer from significant barriers regarding lack of awareness, policies and regulatory voids, lack of knowledge and skills, adequate infrastructure and poor efficiency in the way complex logistics systems are designed (He, Chen, Liu, \& Guo, 2017).

The positive general relationship between low-carbon operations and carbon performance is a signal that stakeholder pressure is effective in terms of transforming pressure into carbon operations practices and in turn into organisational carbon emissions reduction (Damert et al., 2017). This article contributes to the debate on the positive link between low-carbon operations and improved carbon performance, for instance, Doda et al. (2016) and Damert et al. (2017). This article has raised three important insights: (a) different types of stakeholders can influence the adoption of different low-carbon operations practices as a corporate response to climate change; (b) lack of awareness of the source of barriers to the adoption of low-carbon management is critical because stakeholder relationships may not be adequately managed, and developing strong relationships with stakeholders is important to overcoming barriers from the external environment and enhancing organisational competitiveness; and (c) enhancing the environmental capability of suppliers (Genovese et al., 2013) may improve carbon performance comprehension. In summary, building environmental capability through stakeholder engagement is fundamental for continuity and the success of sustainable business strategies, which may include reconfiguring support and supply networks (Dolgui, Ivanov, Sokolov, 2020; Ivanov \& Dolgui, 2020) during and after severe events (Dolgui \& Ivanov, 2020; Queiroz, Ivanov, Dolgui, \& Fosso Wamba, 2020). On one hand, these insights are essential to the production research field, as they foster the scholarly debate on integrating variables from diverse theories to gain a deeper understanding of low-carbon operations from different angles. On the other hand, the insights could provide directions for managers and practitioners as they adopt low-carbon operations by employing sustainable strategies and considering the influence of the network stakeholders.

\subsection{Implications of the findings of this research}


Our research has potention implications for academics, practitioners, industrial policy decisionmakers and environmental regulators:

- Research findings can be relevant in the context of a low carbon economy, and recent discussions on green deals, and net zero production systems.

- First, this work adds original discussion to the debate on adopting low-carbon operations, extending the literature (Böttcher and Müller, 2015) by testing a complex framework and providing a mixture of expected and unexpected findings.

- For academics, our findings regarding the relevance of competitors in exerting pressure towards the adoption of low-carbon operations, as well as the lack of a positive relationship between low-carbon logistics and low-carbon performance requires further investigation and reflection;

- For organisational managers, it adds that stakeholders can act not only as motivators for low-carbon operations, but also as barriers. This implies the necessity of a comprehensive map of stakeholders for each organisation aiming to adopt low-carbon operations practices. This finding also extends the literature on stakeholder pressures by clarifying that stakeholders can act as both motivators and barriers.

- For supply chain managers working in multi-tiered supply chains, it is important to recognise how 'competition' spreads across multiple tiers (upstream and downstream multi-tiered supply chains) and how competitors who are engaged with multiple supply chains at the same time can exert their influence.

- Environmental regulators and industrial policy makers will need to pay additional attention to and create specific support for SMEs adopting low-carbon operations management, as the size of the firm can affect the adoption of these practices.

- Industrial policy makers do not need to be afraid of pushing forward the transition towards a lowcarbon economy, as there is evidence of synergy between low-carbon operations and firms' carbon performance. However, this process can be highly complex and attention must be paid to the relationship between low-carbon logistics and firms' carbon performance.

\section{Conclusion}

This work tests a complex framework aiming at understanding the relationships among stakeholder pressure, low-carbon operations, motivations, barriers, and firms' carbon performance in a sample of Brazilian companies. This research suggests that: (a) stakeholder pressures influence both barriers and motivations for decarbonising operations management practices; (b) stakeholder pressures, especially from competitors, tend to impact low-carbon processes, although their influence on low-carbon products and low-carbon logistics is weaker; (c) both barriers and motivators tend to influence the adoption of low-carbon operations 
management practices; (d) the adoption of low-carbon operations management affects the carbon performance of firms, although low-carbon logistics was an exception; and (e) the larger the firm size, the more intense the adoption of low-carbon processes and logistics.

Thus, these findings contribute to production research literature by demonstrating how to apply aspects of various traditional theories to the field and providing empirical outcomes from an emerging representative economy. Additionally, our work suggests that production research scholars should gain a more in-depth understanding of the barriers and the actor's influence on low-carbon operations projects.

In addition to the managerial and practitioner lens, the findings can be a driver for production managers to support low-carbon operations strategies. In this sense, our work and its outcomes suggest that production managers should gain a deeper awareness of the barriers and motivations related to decarbonising operations practices. In the same line of thought, identifying and managing pressures from stakeholders is also essential. Lastly, production managers should consider the dynamics and complexities of the supply network (Dolgui, Ivanov, \& Sokolov, 2020; Ivanov \& Dolgui, 2020) in their projects. This is fundamental to avoid/minimise errors, rework, and increased costs during low-carbon operations projects as they often require network reconfiguration due to environmental changes.

At the same time as pushing the state-of-the-art literature forward, this work also has certain limitations that should be recognized. First, the research portrays the reality of a specific sample of firms operating in a specific country - Brazil - in the Latin American context. If the context were altered, different research results and insights may be found. The sample of companies considered in this work could have been bigger, so it is possible to suggest the conduction of future research with bigger sample. Thus, additional research efforts should be made in order to enhance the body of knowledge on low-carbon operations, particularly regarding the unexpected results around low-carbon logistics. It is important to develop further scales to measure low-carbon operations management and the potential implications of this construct on firms' performance. Although this work has adopted the perspectives of Liu's (2014) and Böttcher and Müller's (2015) items, it is relevant to keep developing further alternative scales for the topic. Additionally, further examination of the role of the environmental capability of suppliers in improving understanding of carbon performance would be worthwhile. In this work, it is recognized that hypotheses $\mathrm{H} 4, \mathrm{H} 5$ and $\mathrm{H} 6$ may be considered somewhat generic, and it is therefore strongly suggested that future research look further into the relationships between low-carbon operations and firms' performance. It is also relevant to further investigate why H6 was rejected; possible explanations for this outcome, which deserves to be explored further, are: (a) the majority of firms in the sample have not yet fully adopted the practices represented by our scale to measure low-carbon logistics with a clear mission to reduce their emissions (e.g. measurement of carbon emissions from transportation processes; consolidation of shipments to reduce carbon emissions; use of carbon-efficient technologies and modes of transportation); (b) it is possible that the scale used herein, 
inspired by Böttcher and Müller (2015), is not fully adapted to the characteristics of logistics in a country as complex and vast as Brazil; (c) even though companies may have adopted low-carbon logistics practices (Böttcher and Müller, 2015), their emissions per unit of output (example, PCO1, PCO2) can still be high, revealing a weak link between low-carbon logistics and the scale used to measure low-carbon performance of firms; (d) as explained above, the effectiveness of low-carbon logistics depends on collaboration, regulation and other antecedents, which may be not yet be fully developed in Brazil. Undoubtedly, the rejection of H6 deserves further investigation.

Another productive avenue of future research would be to verify whether the organisations studied, or others located in Brazil, have changed their pathway towards a low-carbon economy following the COP 21 agreement. Therefore, the findings of this article may provide a parameter of comparison to understand the effectiveness of stakeholder pressure and the development of environmental capabilities. Finally, we should point out the potential for social desirability bias, which may occur in any sustainability-related research (Roxas and Lindsay 2012).

\section{References}

Abreu, M. C. S., de Freitas, A. R. P., \& Rebouças, S. M. D. P. (2017). Conceptual model for corporate climate change strategy development: Empirical evidence from the energy sector. Journal of Cleaner Production, 165, 382-392.

Amran, A., Ooi, S. K., Wong, C. Y., \& Hashim, F. (2016). Business strategy for climate change: an ASEAN perspective. Corporate Social Responsibility and Environmental Management, 23(4), 213-227.

Arnaut, E., Lopes de Sousa Jabbour, A. B., \& Chiappetta Jabbour, C. J. (2012). Understanding the skills of environmental managers: A study of companies in Brazil's food sector. Environmental Quality Management, 21(4), 41-48.

Baranova, P., \& Meadows, M (2017). Engaging with environmental stakeholders: Routes to building environmental capabilities in the context of the low-carbon economy. Business Ethics: A European Review, 26(2), 112-129.

Barney, J. (1991). Firm resources and sustained competitive advantage. Journal of Management, 17, 99-120.

Benitez, J., Henseler, J., Castillo, A., \& Schuberth, F. (2020). How to perform and report an impactful analysis using partial least squares: Guidelines for confirmatory and explanatory IS research. Information \& Management, 57(2), 103168.

Betts, T. K., Wiengarten, F., \& Tadisina, S. K. (2015). Exploring the impact of stakeholder pressure on environmental management strategies at the plant level: what does industry have to do with it? Journal of Cleaner Production, 92, 282-294.

Boiral, O., Henri, J. F., \& Talbot, D. (2012). Modeling the impacts of corporate commitment on climate change. Business Strategy and the Environment, 21(8), 495-516.

Böttcher, C. F., \& Müller, M. (2015). Drivers, practices and outcomes of low-carbon operations: Approaches of German automotive suppliers to cutting carbon emissions. Business Strategy and the Environment 24(6), 477-498.

Cadez, S., Czerny, A., \& Letmathe, P. (2019. Stakeholder pressures and corporate climate change mitigation strategies. Business Strategy and the Environment 28 (1): 1-14. 
Carbon Disclosure Program. (2015). Gestão da mudança climática na cadeia de valor: desafios e conquistas. Available

http://cdpla.net/sites/default/files/Sum\%C3\%A1rio\%20Executivo\%20do\%20CDP\%20Supply\%20Chain\%20 Brasil\%202014.pdf

Carbon Disclosure Program. (2014). Collaborative action on climate risk. Available on: http://www.ecpar.org/files/documents/cdp-supply-chain-report-2014.pdf

Chu, S. Y., \& Schroeder, H. (2010). Private governance of climate change in Hong Kong: An analysis of drivers and barriers to corporate action. Asian Studies Review, 34(3), 287-308.

Clarkson, M. E. (1995). A stakeholder framework for analyzing and evaluating corporate social performance. Academy of management review, 20, 92-117.

Daddi, T., Todaro, N. M., De Giacomo, M. R., \& Frey, M. (2018). A Systematic Review of the Use of Organization and Management Theories in Climate Change Studies. Business Strategy and the Environment, 27(4), 456-474.

Damert, M., Feng, Y., Zhu, Q., \& Baumgartner, R. J. (2018). Motivating low-carbon initiatives among suppliers: The role of risk and opportunity perception. Resources, Conservation and Recycling, 136, 276-286.

Damert, M., Paul, A., \& Baumgartner, R. J. (2017). Exploring the determinants and long-term performance outcomes of corporate carbon strategies. Journal of Cleaner Production, 160, 123-138.

Darroch, J. (2003). Developing a measure of knowledge management behaviors and practices. Journal of Knowledge Management, 7(5), 41-54.

de Gooyert, V., Rouwette, E., van Kranenburg, H., \& Freeman, E. (2017). Reviewing the role of stakeholders in Operational Research; A stakeholder theory perspective. European Journal of Operational Research, 262(2), 402-410.

Delgado-Ceballos, J., Aragón-Correa, J. A., Ortiz-de-Mandojana, N., \& Rueda-Manzanares, A. (2012). The effect of internal barriers on the connection between stakeholder integration and proactive environmental strategies. Journal of Business Ethics, 107(3), 281-293.

Deng, Z., Lv, L., Huang, W., Wan, L., \& Li, S. (2020). Modelling of carbon utilisation efficiency and its application in milling parameters optimisation. International Journal of Production Research, 58(8), 2406-2420. https://doi.org/10.1080/00207543.2019.1633026

Dey, A. LaGuardia, P. \& Srinivasan, M. (2011). Building sustainability in logistics operations: a research agenda. Management Research Review, 34(11), 1237-1259.

Doda, B., Gennaioli, C., Gouldson, A., Grover, D., \& Sullivan, R. (2016). Are corporate carbon management practices reducing corporate carbon emissions? Corporate Social Responsibility and Environmental Management, 23(5), 257-270.

Dolgui, A., \& Ivanov, D. (2020). Exploring supply chain structural dynamics : New disruptive technologies and disruption risks. International Journal of Production Economics, 107886.

https://doi.org/10.1016/j.ijpe.2020.107886

Dolgui, A., Ivanov, D., \& Sokolov, B. (2020). Reconfigurable supply chain: the X-network. International Journal

of Production Research, 58(13), 4138-4163. https://doi.org/10.1080/00207543.2020.1774679

Dolgui, A. (2018) Leading scholars in Production Research for the 55th volume anniversary of IJPR. International Journal of Production Research, 56(1-2), 1-9, DOI: 10.1080/00207543.2018.1429119

Doty, D. H., \& Glick, W. H. (1998). Common method bias: Does common method variance really bias results? Organizational Research Methods 1(4), 374-406.

Du, Y., Yi, Q., Li, C., \& Liao, L. (2015). Life cycle oriented low-carbon operation models of machinery manufacturing industry. Journal of Cleaner Production, 91,145-157. 
Dubey, R., Gunasekaran, A., Childe, S. J., Papadopoulos, T., Wamba, S. F., \& Song, M. (2016). Towards a theory of sustainable consumption and production: Constructs and measurement. Resources, Conservation and Recycling, 106, 78-89.

Eisenack, K., Moser, S. C., Hoffmann, E., Klein, R. J., Oberlack, C., Pechan, A., ... \& Termeer, C. J. (2014). Explaining and overcoming barriers to climate change adaptation. Nature Climate Change, 4(10), 867.

Field, A. (2016). An Adventure in Statistics: The Reality Enigma. Thousand Oaks: Sage Publications.

Freeman, R. E. (1984). Strategic management: A Stakeholder Approach. Boston: Pitman.

Furlan Matos Alves, M. W., Lopes de Sousa Jabbour, A. B., Kannan, D., \& Chiappetta Jabbour, C. J. (2017). Contingency theory, climate change, and low-carbon operations management. Supply Chain Management: An International Journal, 22(3), 223-236.

Gallego-Álvarez, I., Segura, L., \& Martínez-Ferrero, J. (2015). Carbon emission reduction: the impact on the financial and operational performance of international companies. Journal of Cleaner Production, 103, 149-159.

Garcés-Ayerbe, C., Rivera-Torres, P., \& Murillo-Luna, J. L. (2012). Stakeholder pressure and environmental proactivity: Moderating effect of competitive advantage expectations. Management Decision, 50(2), 189-206.

Gavronski, I., Ferrer, G., \& Paiva, E. L. (2008). ISO 14001 Certification in Brazil: Motivations and Benefits. Journal of Cleaner Production 16 (1), 87-94.

Genovese, A., Lenny Koh, S.C., Bruno, G. and Esposito, E., (2013). Greener supplier selection: state of the art and some empirical evidence. International Journal of Production Research, 51(10), pp.2868-2886.

González-Benito, J. \& González-Benito, O. (2006). The role of stakeholder pressure and managerial values in the implementation of environmental logistics practices. International Journal of Production Research, 44(7), 1353-1373.

Haddad-Sisakht, A., \& Ryan, S. M. (2018). Closed-loop supply chain network design with multiple transportation modes under stochastic demand and uncertain carbon tax. International Journal of Production Economics 195, 118-131.

Hair, J., F. Hult, G. T. M. Ringle, C. M., \& Sarstedt, M. (2017). A Primer on Partial Least Squares Structural Equation Modeling (PLS-SEM) (2nd ed.). Thousand Oaks: Sage Publications.

Hair, J. F., Sarstedt, M., \& Ringle, C. M. (2019). Rethinking some of the rethinking of partial least squares. European Journal of Marketing, 53(4), 566-584.

Han, R., Yu, B. Y., Tang, B. J., Liao, H., \& Wei, Y. M. (2017). Carbon emissions quotas in the Chinese road transport sector: A carbon trading perspective. Energy Policy, 106, 298-309.

Hart, S. L. \& Dowell, G. (2011). Invited editorial: A natural-resource-based view of the firm fifteen years after. Journal of management, 37(5), 1464-1479.

He, Z., Chen, P., Liu, H., \& Guo, Z. (2017). Performance measurement system and strategies for developing low-carbon logistics: A case study in China. Journal of Cleaner Production, 156, 395-405. https://doi.org/10.1016/j.jclepro.2017.04.071

Henriques, J., \& Catarino, J. (2016). Motivating towards energy efficiency in small and medium enterprises. Journal of Cleaner Production, 139, 42-50.

Henseler, J. (2018). Partial least squares path modeling: Quo vadis? Quality \& Quantity, 52(1), 1-8.

Herrmann, J. \& Guenther, E. (2017). Exploring a scale of organizational barriers for enterprises' climate change adaptation strategies. Journal of Cleaner Production, 160, 38-49. 
Hoffman, A. J. (2005), Climate change strategy: The business logic behind voluntary greenhouse gas reductions. California Management Review, 47(3), 21-46.

Holt, D., \& Ghobadian, A. (2009). An empirical study of green supply chain management practices amongst UK manufacturers. Journal of Manufacturing Technology Management 20 (7), 933-956

Hoogendoorn, B. Guerra, D. \& van der Zwan, P. (2015). What drives environmental practices of SMEs? Small Business Economics, 44(4), 759-781.

Hui, B. S., \& Wold, H. (1982). Consistency and consistency at large of partial least squares estimates. In K. G. Joreskog \& H. Wold (Eds.), Systems under indirect observation: Causality, structure, prediction (Vol. 2, pp. 119-130). Amsterdam: North Holland.

Hyatt, D. G., \& Berente, N. (2017). Substantive or symbolic environmental strategies? Effects of external and internal normative stakeholder pressures. Business Strategy and the Environment, 26(8), 1212-1234.

Ivanov, D., \& Dolgui, A. (2020). Viability of intertwined supply networks: extending the supply chain resilience angles towards survivability. A position paper motivated by COVID-19 outbreak. International Journal of Production Research, 58(10), 2904-2915. https://doi.org/10.1080/00207543.2020.1750727

Jabbour, C. J. C. (2010). In the eye of the storm: exploring the introduction of environmental issues in the production function in Brazilian companies. International Journal of Production Research, 48(21), 6315-6339.

Jabbour, C.J.C., de Sousa Jabbour, A.B.L., Govindan, K., Teixeira, A.A. and de Souza Freitas, W.R., 2013. Environmental management and operational performance in automotive companies in Brazil: the role of human resource management and lean manufacturing. Journal of Cleaner Production, 47, pp.129140.

Jabbour, A.B.L.S., Jabbour, C.J.C, Sarkis, J., Gunasekaran, A., Furlan Matos Alves, M.W. and Ribeiro, D.A. (2019). Decarbonisation of operations management-looking back, moving forward: a review and implications for the production research community. International Journal of Production Research, 57(15-16), pp.4743-4765.

Jeswani, H. K., Wehrmeyer, W., \& Mulugetta, Y. (2008). How warm is the corporate response to climate change? Evidence from Pakistan and the UK. Business Strategy and the Environment, 17(1), 46-60.

Ketokivi, M., \& McIntosh, C. N. (2017). Addressing the endogeneity dilemma in operations management research: Theoretical, empirical, and pragmatic considerations. Journal of Operations Management, 52, 1-14.

Klassen, R. D., \& Whybark, D. C. (1999). The Impact of Environmental Technologies on Manufacturing Performance. Academy of Management Journal 42(6), 599-615

Kock, N. (2017). Common method bias: A full collinearity assessment method for PLS-SEM. In H. Latan \& R. Noonan (Eds.), Partial Least Squares Path Modeling. Cham: Springer International.

Laosirihongthong, T., Adebanjo, D., \& Choon Tan, K. (2013). Green supply chain management practices and performance. Industrial Management \& Data Systems, 113(8), 1088-1109. https://doi.org/10.1108/IMDS-04-2013-0164

Latan, H. (2018). PLS path modeling in hospitality and tourism research: The golden age and days of future past. In F. Ali, M. S. Rasoolimanesh, \& C. Cobanoglu (Eds.), Application of Partial Least Squares Structural Equation Modeling (PLS-SEM) in Tourism and Hospitality Research (pp. 1-35). Bingley: Emerald.

Latan, H., Chiappetta Jabbour, C. J., Lopes de Sousa Jabbour, A. B., Renwick, D. W. S., Wamba, S. F., \& Shahbaz, M. (2018). 'Too-much-of-a-good-thing'? The role of advanced eco-learning and contingency factors on the relationship between corporate environmental and financial performance. Journal of Environmental Management, 220, 163-172. 
Lee, S. Y., \& Kim, Y. H. (2015). Antecedents and Consequences of Firms' Climate Change Management Practices: Stakeholder and Synergistic Approach. Sustainability, 7(11), 14521-14536.

Lee, S-Y. (2012). Corporate carbon strategies in responding to climate change. Business Strategy and the Environment, 21(1), 33-48.

Littlewood, D., Decelis, R., Hillenbrand, C., \& Holt, D. (2018). Examining the drivers and outcomes of corporate commitment to climate change action in European high emitting industry. Business Strategy and the Environment 27(8), 1437-1449.

Liu, Y. (2012). An empirical research of awareness, behavior and barriers to enact carbon management of industrial firms in China. Science of the Total Environment, 425, 1-8.

Liu, Y. (2014). Barriers to the adoption of low-carbon production: A multiple-case study of Chinese industrial firms. Energy policy, 67, 412-421.

Liu, Y. (2018). Exploring the Relationship between External Positive-Negative Pressures and the Carbon Management Behaviour of Industrial Firms. Corporate Social Responsibility and Environmental Management 25(4), 628-641.

Luo, Z., Gunasekaran, A., Dubey, R., Childe, S. J., \& Papadopoulos, T. (2017). Antecedents of low-carbon emissions supply chains. International Journal of Climate Change Strategies and Management, 9(5), 707-727.

Mackenzie, S. B., \& Podsakoff, P. M. (2012). Common method bias in marketing: Causes, mechanisms, and procedural remedies. Journal of Retailing, 88(4), 542-555.

Malhotra, N. K., Schaller, T. K., \& Patil, A. (2017). Common method variance in advertising research: When to be concerned and how to control for it. Journal of Advertising, 46(1), 193-212.

Mani, V., Gunasekaran, A., \& Delgado, C. (2018). Enhancing supply chain performance through supplier social sustainability: An emerging economy perspective. International Journal of Production Economics, 195, 259-272.

Marcondes, D., \& Canto, R (2015) O sopro de esperança da COP21. Carta Capital. Available on: https://www.cartacapital.com.br/revista/881/sopro-de-esperanca Accessed in October, 2016.

Martín de Castro, G. Amores-Salvadó, J. \& Navas-López, J. E. (2016). Environmental management systems and firm performance: improving firm environmental policy through stakeholder engagement. Corporate Social Responsibility and Environmental Management, 23(4), 243-256.

Ng, S. T. Skitmore, M. \& Cheung. J.N.H. (2013). Organisational obstacles to reducing carbon emissions in Hong Kong. Habitat International, 40, 119-126.

Noonan, R., \& Wold, H. (1986). Partial Least Squares Path Analysis. In T. Husen \& T. N. Postlethwaite (Eds.), The International Encyclopedia of Education (Vol. 7, pp. 3769-3775). Oxford: Pergamon Press.

Pålsson, H. \& Kovács, G. (2014). Reducing transportation emissions: A reaction to stakeholder pressure or a strategy to increase competitive advantage. International Journal of Physical Distribution \& Logistics Management, 44(4), 283-304.

Paul, A. Lang, J. W. \& Baumgartner, R. J. (2017). A multilevel approach for assessing business strategies on climate change. Journal of Cleaner Production, 160, 50-70.

Peel, M. J. (2018). Addressing unobserved selection bias in accounting studies: The bias minimization method. European Accounting Review, 27(1), 173-183.

Penz, E., \& Polsa, P. (2018). How do companies reduce their carbon footprint and how do they communicate these measures to stakeholders? Journal of Cleaner Production, 195, 1125-1138. 
Qian, C., Wang, S., Liu, X., \& Zhang, X. (2019). Low-Carbon Initiatives of Logistics Service Providers: The Perspective of Supply Chain Integration. Sustainability, 11(12), 3233. https://doi.org/10.3390/su11123233

Qin, J., Han, Y., Wei, G., \& Xia, L. (2020). The value of advance payment financing to carbon emission reduction and production in a supply chain with game theory analysis. International Journal of Production Research, 58(1), 200-219. https://doi.org/10.1080/00207543.2019.1671626

Queiroz, M. M., Ivanov, D., Dolgui, A., \& Fosso Wamba, S. (2020). Impacts of epidemic outbreaks on supply chains: mapping a research agenda amid the COVID-19 pandemic through a structured literature review. Annals of Operations Research. https://doi.org/10.1007/s10479-020-03685-7

Ramli, N. A., Latan, H., \& Nartea, G. V. (2018). Why should PLS-SEM be used rather than regression? Evidence from the capital structure perspective. In N. K. Avkiran \& C. M. Ringle (Eds.), Partial Least Squares Structural Equation Modeling: Recent Advances in Banking and Finance (pp. 171-209). Cham: Springer International.

Rao, P. (2002). Greening the supply chain: A new initiative in South East Asia. International Journal of Operations \& Production Management 22(6), 632-655.

Ringle, C. M. Wende, S. \& Becker, J-M. (2015), SmartPLS3.Boenningstedt: SmartPLS GmbH. http://www.smartpls.com.

Roxas, B., \& Lindsay, V. (2012). Social desirability bias in survey research on sustainable development in small firms: An exploratory analysis of survey mode effect. Business Strategy and the Environment 21(4), 223235.

Sarkis, J. Gonzalez-Torre, P. \& Adenso-Diaz, B. (2010). Stakeholder pressure and the adoption of environmental practices: The mediating effect of training. Journal of Operations Management, 28(2), 163-176.

Savage, G. T., Nix, T. W., Whitehead, C. J., \& Blair, J. D. (1991). Strategies for assessing and managing organizational stakeholders. The Executive, 5(2), pp. 61-75.

Sekaran, U., \& Bougie, R. (2016). Research Methods for Business: A Skill-Building Approach (7th ed.). Chichester: Wiley.

Seles, B. M. R. P., Lopez de Sousa Jabbour, A. B., Chiappetta Jabbour, C. J., \& Dangelico, R. M. (2016). The green bullwhip effect, the diffusion of green supply chain practices, and institutional pressures: Evidence from the automotive sector. International Journal of Production Economics, 182, 342-355.

Sprengel, D. C. \& Busch, T. (2011). Stakeholder engagement and environmental strategy-the case of climate change. Business Strategy and the Environment, 20(6), 351-364.

Synodinos, N. E. (2003). The "art" of questionnaire construction: some important considerations for manufacturing studies. Integrated Manufacturing Systems, 14(3), 221-237.

Tang, C. S. \& Zhou, S. (2012). Research advances in environmentally and socially sustainable operations. European Journal of Operational Research, 223(3), 585-594.

Teixeira, A. A., Chiappetta Jabbour, C. J., \& Lopez de Sousa Jabbour, A. B. (2012). Relationship between green management and environmental training in companies located in Brazil: A theoretical framework and case studies. International Journal of Production Economics, 140(1), 318-329.

Tsalis, T. A. \& Nikolaou, I. E. (2017). Assessing the effects of climate change regulations on the business community: A system dynamic approach. Business Strategy and the Environment, 26(6), 826-843.

Valero-Gil, J., Rivera-Torres, P., \& Garcés-Ayerbe, C. (2017). How is environmental proactivity accomplished? Drivers and barriers in firms' pro-environmental change process. Sustainability, 9(8), 1327.

Wang, Z., \& Sarkis, J. (2017). Corporate social responsibility governance, outcomes, and financial performance. Journal of Cleaner Production, 162, 1607-1616. 
Weber, G. \& Cabras, I. (2017). The transition of Germany's energy production, green economy, low-carbon economy, socio-environmental conflicts, and equitable society. Journal of Cleaner Production, 167, 1222-1231.

Wesseling, J. H., Lechtenböhmer, S., Åhman, M., Nilsson, L. J., Worrell, E., \& Coenen, L. (2017). The transition of energy intensive processing industries towards deep decarbonization: characteristics and implications for future research. Renewable and Sustainable Energy Reviews, 79, 1303-1313.

Wooldridge, J. M. (2020). Introductory Econometrics: A Modern Approach (7th ed.). South-Western: Cengage Learning.

Wold, H. (1986). Factors Influencing the Outcome of Economic Sanctions: An Application of Soft Modeling. In N. N (Ed.), Trabajos de Estadistica Y de InvestigacionOperativa: Homenaje al ProfesorSixto Rios (Vol. 36, pp. 325-337). Haifa: University of Haifa International Workshop on Conflict Resolution.

Yafei, Z., Lianghua, C., \& Yi, F. (2018). Research on low-carbon strategies in supply chain with environmental regulations based on differential game. Journal of Cleaner Production, 177, 527-546.

Zailani, H. M., Eltayeb, T. K., Hsu, C. C., \& Tan, K. C. (2012). The impact of external institutional drivers and internal strategy on environmental performance. International Journal of Operations \& Production Management 32(6), 721-745.

Zhenggang, H., Peng, C., Haitao, L., \& Zhaoxia, G. (2017). Performance measurement system and strategies for developing low-carbon logistics: A case study in China. Journal of Cleaner Production, 156, 395-405.

Zuraidah, R. M., Abdekhodaee, R. M. \& Nagarajah, R. (2014). Stakeholders' involvements in the implementation of proactive environmental practices: Linking environmental practices and environmental performances in SMEs. Management of Environmental Quality: An International Journal, 25(2), 132-149.

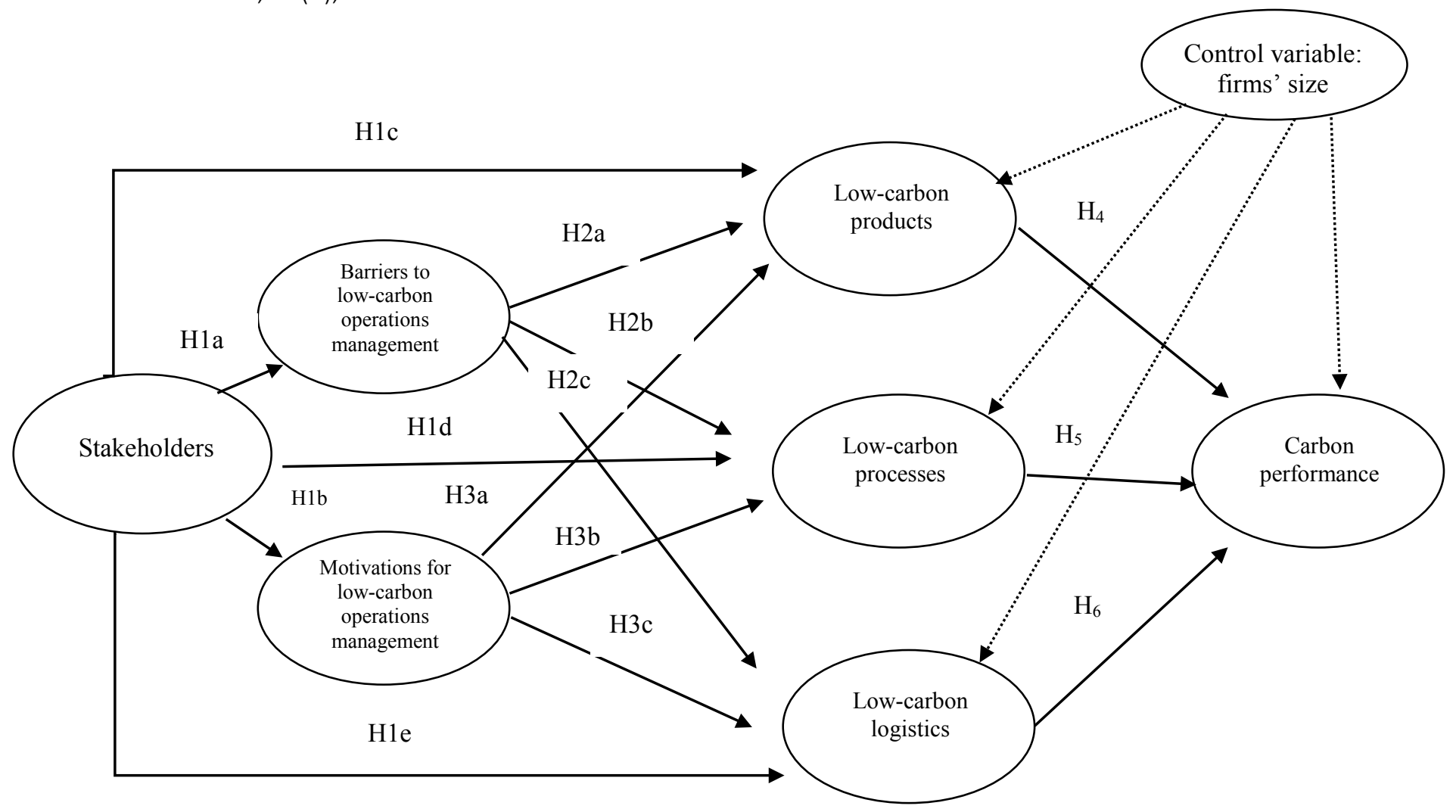

Figure 1. Research Framework and Hypotheses 


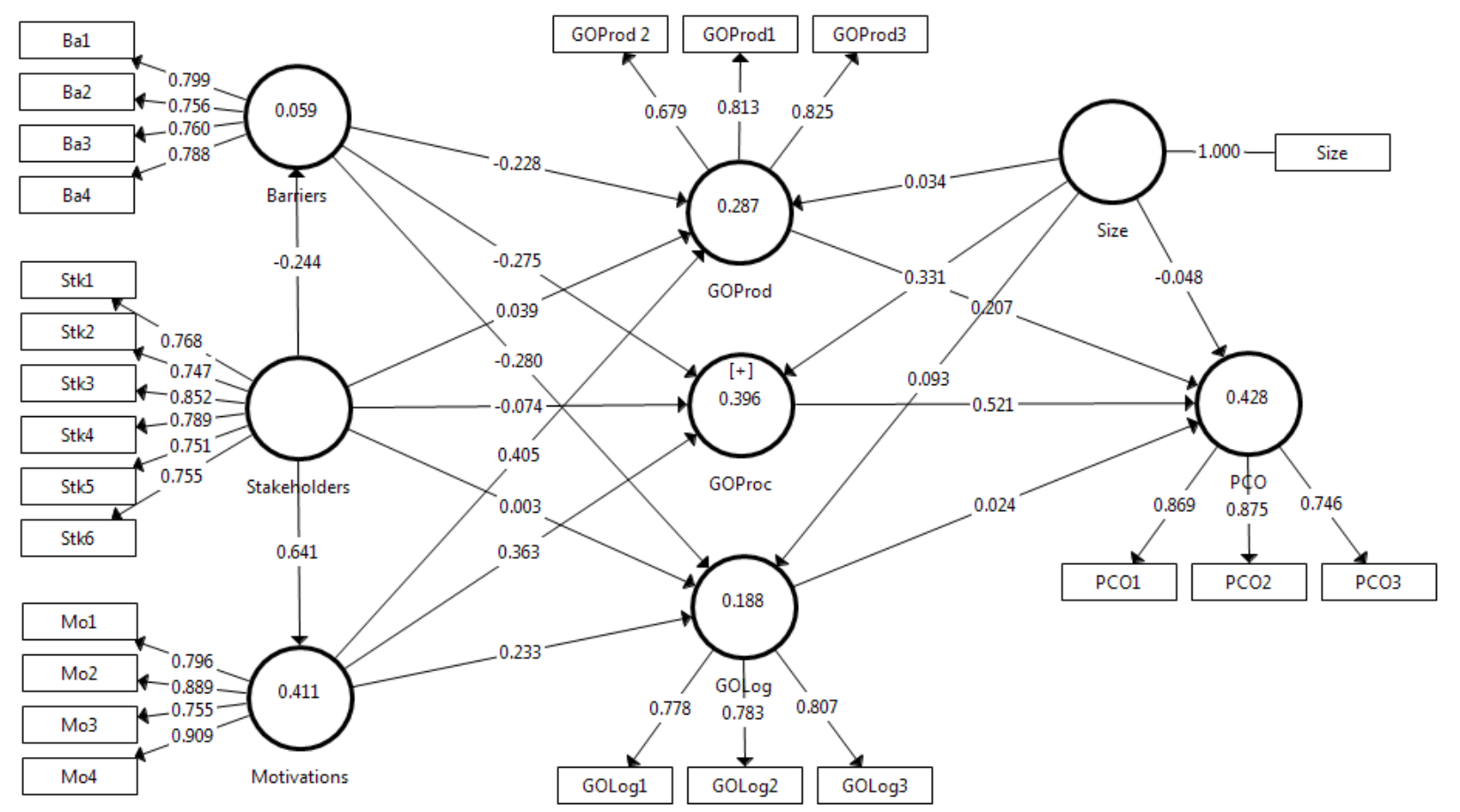

Figure 2. Evaluation of the Measurement Model

Table 1.

Selected Examples of Motivations and Barriers to Organisational Low-carbon Actions

\begin{tabular}{|c|c|c|}
\hline Research & Motivations & Barriers \\
\hline Okereke (2007) & $\begin{array}{l}\text { - } \text { Profit } \\
\text { - } \text { Credibility and influence in the } \\
\text { - } \text { Risk aversion } \\
\text { - Ethical considerations }\end{array}$ & $\begin{array}{l}\text { - Lack of policy } \\
\text { - Uncertainty of governmental actions } \\
\text { - Uncertainty about the market }\end{array}$ \\
\hline Jeswani et al. (2008) & $\begin{array}{l}\text { - Cost savings } \\
\text { - Corporate goals } \\
\text { - Commitment management } \\
\text { - Regulatory compliance }\end{array}$ & $\begin{array}{l}\text { - Lack of knowledge } \\
\text { - Lack of availability of technology } \\
\text { - } \text { Absence of governmental policies } \\
\text { - High cost } \\
\text { - Lack of financial resources }\end{array}$ \\
\hline $\begin{array}{l}\text { Chu and Schroeder } \\
\text { (2010) }\end{array}$ & $\begin{array}{l}\text { - } \text { Competitive advantage } \\
\text { - Reputation } \\
\text { - } \text { Leadership of organisational } \\
\text { - } \text { management } \\
\text { - Reduction of risk } \\
\text { - Regulatory pressure }\end{array}$ & $\begin{array}{l}\text { - Lack of legal requirements } \\
\text { - Lack of capacity and knowledge } \\
\text { - Lack of management support }\end{array}$ \\
\hline Boiral et al. (2012) & $\begin{array}{l}\text { - Market opportunity } \\
\text { - } \text { Reduction of production costs } \\
\text { - Increased value for shareholders }\end{array}$ & - $\quad \mathrm{N} / \mathrm{A}$ \\
\hline
\end{tabular}




\begin{tabular}{|c|c|c|}
\hline & $\begin{array}{l}\text { - Requirement of customers } \\
\text { - Access to capital }\end{array}$ & \\
\hline Ng et al. (2013) & $\begin{array}{l}\text { - Reduction of costs } \\
\text { - Increase of market prospects. }\end{array}$ & $\begin{array}{l}\text { - Lack of environmental market awareness } \\
\text { - Limited budget } \\
\text { - Customer attitudes } \\
\text { - Top management }\end{array}$ \\
\hline Liu (2014) & - N/A & $\begin{array}{l}\text { - } \text { Structural } \\
\text { - } \text { Regulation } \\
\text { - } \text { Cultural } \\
\text { - } \text { Contextual } \\
\end{array}$ \\
\hline Galbreath (2014) & - N/A & $\begin{array}{l}\text { - Lack of perception of risks caused by climate } \\
\text { change } \\
\text { - Lack of clarity about the economic benefits } \\
\text { generated by processes/products changes }\end{array}$ \\
\hline $\begin{array}{c}\text { Palsson and Kovács } \\
\text { (2014) }\end{array}$ & $\begin{array}{l}\text { - } \text { Profit } \\
\text { - } \text { Competitiveness } \\
\text { - Market advantage } \\
\text { - Customer requirements } \\
\text { - Investor requirements } \\
\text { - Social responsibility } \\
\text { - Environmental awareness of } \\
\quad \text { employees }\end{array}$ & - N/A \\
\hline $\begin{array}{c}\text { Böttcher and Müller } \\
\text { (2015) }\end{array}$ & $\begin{array}{l}\text { - Improvement of image } \\
\text { - Market opportunity } \\
\text { - } \text { Cost reduction } \\
\text { - Differentiation among competitors } \\
\text { - Rewarding customers } \\
\text { - Access to funds }\end{array}$ & - N/A \\
\hline
\end{tabular}

Table 2.

Summary of Constructs and Indicators of the Research

\begin{tabular}{|c|c|c|}
\hline Construct (inspired by) & Indicators & Questions and Scales \\
\hline $\begin{array}{l}\text { Stakeholders } \\
\text { (Clarkson, 1995) }\end{array}$ & $\begin{array}{l}\text { - } \text { Customers (Stk1) } \\
\text { - Government (Stk2) } \\
\text { - } \text { Competitors (Stk3) } \\
\text { - Employees (Stk4) } \\
\text { - Suppliers (Stk5) } \\
\text { - } \text { Media (Stk6) }\end{array}$ & $\begin{array}{l}\text { Managers were asked to what extent their } \\
\text { organisation's efforts to reduce } \\
\text { carbon emissions were affected by each of } \\
\text { those stakeholders } \\
\text { Level of influence: from no influence to } \\
\text { strong influence ( } 5 \text { point Likert-scale). }\end{array}$ \\
\hline
\end{tabular}




\begin{tabular}{|c|c|c|}
\hline $\begin{array}{l}\text { Barriers } \\
\text { (Liu, 2014) }\end{array}$ & $\begin{array}{l}\text { - There is a social and consumer context that } \\
\text { does not encourage the reduction of } \mathrm{CO}_{2} \\
\text { emissions by the company ( } \mathrm{Ba} 1) \\
\text { - There is an internal organisational culture } \\
\text { that does not encourage the reduction of } \\
\left.\mathrm{CO}_{2} \text { emissions where I work ( } \mathrm{Ba} 2\right) \\
\text { - There is a political and governmental } \\
\text { context that does not encourage the } \\
\text { reduction of } \mathrm{CO}_{2} \text { emissions where I work } \\
\text { (Ba3) } \\
\text { - It is difficult to include the topic of reducing } \\
\mathrm{CO}_{2} \text { emissions where I work (Ba4) }\end{array}$ & $\begin{array}{l}\text { Managers were asked about the barriers to } \\
\text { carbon emission reduction within their } \\
\text { organisations. } \\
\text { Level of agreement: from totally disagree } \\
\text { to totally agree ( } 5 \text { point Likert-scale). }\end{array}$ \\
\hline $\begin{array}{l}\text { Motivations } \\
\text { (Böttcher and Müller, } \\
\text { 2015) }\end{array}$ & $\begin{array}{l}\text { - Image improvement (Mo1) } \\
\text { - Marketing opportunity (Mo2) } \\
\text { - } \text { Cost reduction (Mo3) } \\
\text { - Differentiation from competitors (Mo4) }\end{array}$ & $\begin{array}{l}\text { Managers were asked about the } \\
\text { motivations for carbon emission reduction } \\
\text { within their organisations. } \\
\text { Level of motivation: from not motivating to } \\
\text { totally motivating ( } 5 \text { point Likert-scale) }\end{array}$ \\
\hline $\begin{array}{l}\text { Low-carbon products } \\
\text { (Böttcher and Müller, } \\
\text { 2015) }\end{array}$ & $\begin{array}{l}\text { - Use of life cycle assessment (carbon } \\
\text { footprint) (GOProd1) } \\
\text { - Use of renewable and/or recycled raw } \\
\text { materials (GOProd2) } \\
\text { - Reduction of carbon emissions in utilization } \\
\text { phase (GOProd3) }\end{array}$ & $\begin{array}{l}\text { Managers were asked about which low- } \\
\text { carbon products, processes, and logistics } \\
\text { practices their organisations have adopted. }\end{array}$ \\
\hline $\begin{array}{l}\text { Low-carbon processes } \\
\text { (Böttcher and Müller, } \\
\text { 2015) }\end{array}$ & $\begin{array}{l}\text { - Measurement of carbon emissions in } \\
\text { production processes (GOProc1) } \\
\text { - Use of energy/carbon efficient equipment } \\
\text { (GOProc2) } \\
\text { - Use of low-carbon/carbon-free energy } \\
\text { sources (GOProc3) }\end{array}$ & $\begin{array}{l}\text { Level of adoption: from no adoption to } \\
\text { completely adopted ( } 5 \text { point Likert-scale) }\end{array}$ \\
\hline $\begin{array}{l}\text { Low-carbon logistics } \\
\text { (Böttcher and Müller, } \\
\text { 2015) }\end{array}$ & $\begin{array}{l}\text { - Measurement of carbon emissions of } \\
\text { transportation processes (GOLog1) } \\
\text { - Consolidation of shipments to reduce } \\
\text { carbon emissions (GOLog2) } \\
\text { - Use of carbon-efficient technologies and } \\
\text { modes for transportation (GOLog3) }\end{array}$ & \\
\hline
\end{tabular}




\begin{tabular}{|c|l|l|}
\hline $\begin{array}{c}\text { Carbon performance } \\
\text { (Böttcher and Müller, }\end{array}$ & $\begin{array}{l}\text { - Energy use (per unit of output) (PCO1) } \\
\text { 2015) } \\
\text { (PCO2) emissions (per unit of output) }\end{array}$ & $\begin{array}{l}\text { Managers were asked about their } \\
\text { - Use of carbon-intensive materials (per unit } \\
\text { of output) (PCO3) } \\
\text { emission reduction over time. }\end{array}$ \\
$\begin{array}{l}\text { Level of improvement: from decrease a lot } \\
\text { to improve a lot (5 point Likert-scale) }\end{array}$ \\
\hline
\end{tabular}

Table 3.

Sample Distribution

\begin{tabular}{c|c}
\hline Features & Percentage \\
\hline Micro-sized (1-19 employees) & $9 \%$ \\
\hline Small-sized (20-99 employees) & $22 \%$ \\
\hline Medium-sized (100-499 employees) & $42 \%$ \\
\hline Large-sized (more than 500 employees) & $27 \%$ \\
\hline ISO 9001 Certified company & $75 \%$ \\
\hline ISO 14001 Certified company & $54 \%$ \\
\hline
\end{tabular}

Table 4.

Non-Response Bias Test

\begin{tabular}{c|cc}
\hline Constructs & Sig. Levene's Test & $\begin{array}{c}\text { Sig. t-test for Equality of } \\
\text { Means }\end{array}$ \\
\hline Stakeholders & 0.112 & 0.296 \\
Barriers & 0.113 & 0.091 \\
Motivations & 0.306 & 0.727 \\
Low-carbon Products & 0.192 & 0.118 \\
Low-carbon Processes & 0.560 & 0.190 \\
Low-carbon Logistics & 0.181 & 0.061 \\
Carbon Performance & 0.103 & 0.111 \\
\hline
\end{tabular}

Table 5.

Construct Indicators and Measurement Model Results

\begin{tabular}{cccccc}
\hline Latent Variables & Items/Indicators & FL & AVE & $\rho_{c}$ & $\rho_{A}$ \\
\hline Stakeholders & Stk1 & 0.768 & & & \\
& Stk2 & 0.747 & & & 0.882 \\
Stk3 & 0.852 & 0.605 & 0.902 & \\
Stk4 & 0.789 & & & \\
Stk5 & 0.751 & & & \\
Barriers & Stk6 & 0.755 & & & \\
& Ba1 & 0.799 & & & \\
& Ba2 & 0.756 & 0.602 & & \\
Ba3 & 0.760 & & &
\end{tabular}




\begin{tabular}{|c|c|c|c|c|c|}
\hline \multirow[t]{4}{*}{ Motivations } & Mo1 & 0.796 & & \multirow{4}{*}{0.905} & \multirow{4}{*}{0.868} \\
\hline & Mo2 & 0.889 & \multirow{3}{*}{0.705} & & \\
\hline & Mo3 & 0.755 & & & \\
\hline & Mo4 & 0.909 & & & \\
\hline \multirow[t]{3}{*}{ Low-carbon Products } & GOProd1 & 0.813 & \multirow{3}{*}{0.601} & \multirow{3}{*}{0.818} & \multirow{3}{*}{0.682} \\
\hline & GOProd2 & 0.679 & & & \\
\hline & GOProd3 & 0.825 & & & \\
\hline \multirow[t]{3}{*}{ Low-carbon Processes } & GOProc1 & 0.666 & \multirow{3}{*}{0.621} & \multirow{3}{*}{0.829} & \multirow{3}{*}{0.720} \\
\hline & GOProc2 & 0.854 & & & \\
\hline & GOProc3 & 0.830 & & & \\
\hline \multirow[t]{3}{*}{ Low-carbon Logistics } & GOLog1 & 0.778 & \multirow{3}{*}{0.623} & \multirow{3}{*}{0.832} & \multirow{3}{*}{0.697} \\
\hline & GOLog2 & 0.783 & & & \\
\hline & GOLog3 & 0.807 & & & \\
\hline \multirow[t]{3}{*}{ Carbon Performance } & PCO1 & 0.869 & \multirow{3}{*}{0.692} & \multirow{3}{*}{0.870} & \multirow{3}{*}{0.791} \\
\hline & PCO2 & 0.875 & & & \\
\hline & PCO3 & 0.746 & & & \\
\hline
\end{tabular}

Table 6.

Correlations and Discriminant Validity Results

\begin{tabular}{ccccccccccc}
\hline Construct & Mean & S.D & 1 & 2 & 3 & 4 & 5 & 6 & 7 \\
\hline Barriers & 3.13 & 1.07 & 1 & 0.438 & 0.506 & 0.428 & 0.226 & 0.350 & 0.274 \\
GOLog & 2.03 & 1.29 & $-0.347^{*}$ & 1 & 0.787 & 0.823 & 0.390 & 0.549 & 0.293 \\
GOProc & 2.58 & 1.33 & $-0.409^{*}$ & $0.527^{*}$ & 1 & 0.832 & 0.559 & 0.834 & 0.355 \\
GOProd & 2.32 & 1.23 & $-0.319^{*}$ & $0.570^{*}$ & $0.549^{*}$ & 1 & 0.608 & 0.702 & 0.459 \\
Motivations & 2.99 & 1.27 & -0.178 & 0.302 & $0.424^{*}$ & $0.477^{*}$ & 1 & 0.262 & 0.735 \\
PCO & 3.46 & 0.59 & $-0.302^{*}$ & 0.406 & $0.625^{*}$ & $0.498^{*}$ & 0.216 & 1 & 0.209 \\
Stakeholders & 2.46 & 1.06 & $-0.244^{*}$ & 0.238 & 0.286 & 0.361 & $0.641^{*}$ & 0.168 & 1
\end{tabular}

*Correlation is significant at the 0.05 level (2-tailed). Below the diagonal elements are the correlations between the construct values. Above the diagonal elements are the HTMT values.

Table 7.

Structural Model Results

\begin{tabular}{|c|c|c|c|c|c|c|}
\hline Constructs & $\mathrm{R}^{2}$ & Adj. $R^{2}$ & $p$ & $Q^{2}$ & VIF & AFVIF \\
\hline Stakeholders & - & - & $0.063-0.699$ & - & 1.755 & - \\
\hline Barriers & 0.059 & 0.049 & $0.065-0.112$ & 0.051 & 1.123 & - \\
\hline Motivations & 0.411 & 0.405 & $0.039-0.135$ & 0.406 & 1.711 & - \\
\hline GOProd & 0.287 & 0.253 & 0.044 & 0.255 & 1.711 & - \\
\hline GOProc & 0.396 & 0.368 & 0.247 & 0.370 & 1.923 & - \\
\hline GOLog & 0.188 & 0.150 & 0.001 & 0.152 & 1.640 & - \\
\hline PCO & 0.428 & 0.401 & - & 0.404 & - & 0.185 \\
\hline
\end{tabular}


Table 8.

Relationships between Variables

\begin{tabular}{lccccc}
\hline \multicolumn{1}{c}{ Structural path } & Coef $(\beta)$ & Std. deviation & $p$-values & 95\% BCa Cl & Conclusion \\
\hline Stakeholders $\rightarrow$ Barriers & -0.244 & 0.109 & 0.013 & $(-0.411,-0.050)^{*}$ & H1a supported \\
Stakeholders $\rightarrow$ Motivations & 0.641 & 0.079 & 0.000 & $(0.481,0.749)^{* *}$ & H1b supported \\
Stakeholders $\rightarrow$ GOProd & 0.039 & 0.121 & 0.372 & $(0.000,0.089)^{\text {n.s }}$ & H1c not supported \\
Stakeholders $\rightarrow$ GOProc & -0.074 & 0.082 & 0.042 & $(-0.210,-0.002)^{*}$ & H1d supported \\
Stakeholders $\rightarrow$ GOLog & 0.003 & 0.112 & 0.489 & $(0.000,0.001)^{\text {n.s }}$ & H1e not supported \\
Barriers $\rightarrow$ GOProd & -0.228 & 0.102 & 0.012 & $(-0.392,-0.054)^{* *}$ & H2a supported \\
Barriers $\rightarrow$ GOProc & -0.275 & 0.086 & 0.001 & $(-0.399,-0.110)^{* *}$ & H2b supported \\
Barriers $\rightarrow$ GOLog & -0.280 & 0.104 & 0.003 & $(-0.432,-0.086)^{* *}$ & H2c supported \\
Motivations $\rightarrow$ GOProd & 0.405 & 0.162 & 0.006 & $(0.097,0.645)^{*}$ & H3a supported \\
Motivations $\rightarrow$ GOProc & 0.363 & 0.139 & 0.004 & $(0.127,0.583)^{*}$ & H3b supported \\
Motivations $\rightarrow$ GOLog & 0.233 & 0.141 & 0.049 & $(0.125,0.483)^{* *}$ & H3c supported \\
GOProd $\rightarrow$ PCO & 0.207 & 0.093 & 0.013 & $(0.062,0.355)^{* *}$ & H4 supported \\
GOProc $\rightarrow$ PCO & 0.521 & 0.090 & 0.000 & $(0.375,0.667)^{* *}$ & H5 supported \\
GOLog $\rightarrow$ PCO & 0.024 & 0.066 & 0.360 & $(0.000,0.060)^{\text {n.s }}$ & H6 not supported \\
\hline
\end{tabular}

Note: ${ }^{* *}$ and ${ }^{*}$ statistically significant at the 1 percent and 5 percent levels, respectively; n.s is not significant

Table 9.

Endogneity Test

\begin{tabular}{lcccc}
\hline \multicolumn{1}{c}{ Structural path } & Coef $(\boldsymbol{\beta})$ & Std. deviation & z & Conclusion \\
\hline Stakeholders $\rightarrow$ Barriers & -0.153 & 0.068 & $-2.23^{*}$ & Not different \\
Stakeholders $\rightarrow$ Motivations & 0.548 & 0.069 & $7.87^{* *}$ & Not different \\
Stakeholders $\rightarrow$ GOProd & 0.203 & 0.157 & 1.29 & Not different \\
Stakeholders $\rightarrow$ GOProc & -0.267 & 0.080 & $-3.34^{* *}$ & Not different \\
Stakeholders $\rightarrow$ GOLog & 0.172 & 0.163 & 1.05 & Not different \\
Barriers $\rightarrow$ GOProd & -0.148 & 0.063 & $-2.35^{* *}$ & Not different \\
Barriers $\rightarrow$ GOProc & -0.263 & 0.086 & $-3.06^{* *}$ & Not different \\
Barriers $\rightarrow$ GOLog & -0.120 & 0.044 & $-2.70^{* *}$ & Not different \\
Motivations $\rightarrow$ GOProd & 0.304 & 0.063 & $4.81^{* *}$ & Not different
\end{tabular}




$\begin{array}{lcccc}\text { Motivations } \rightarrow \text { GOProc } & 0.316 & 0.069 & 4.56^{* *} & \text { Not different } \\ \text { Motivations } \rightarrow \text { GOLog } & 0.218 & 0.071 & 3.04^{* *} & \text { Not different } \\ \text { GOProd } \rightarrow \text { PCO } & 0.257 & 0.046 & 5.54^{* *} & \text { Not different } \\ \text { GOProc } \rightarrow \text { PCO } & 0.283 & 0.039 & 7.16^{* *} & \text { Not different } \\ \text { GOLog } \rightarrow \text { PCO } & 0.190 & 0.146 & 1.30 & \text { Not different }\end{array}$

Note: ${ }^{* *}$ and ${ }^{*}$ are statistically significant at the 1 percent and 5 percent levels, respectively. 